Caine DJ, Maffulli N (eds): Epidemiology of Pediatric Sports Injuries.

Individual Sports. Med Sport Sci. Basel, Karger, 2005, vol 48, pp 8-17

\title{
Equestrian Injuries
}

\author{
Paul McCrory ${ }^{\mathrm{a}}$, Michael Turner ${ }^{\mathrm{b}}$ \\ ${ }^{a}$ Centre for Health, Exercise and Sports Medicine and Brain Research Institute, \\ University of Melbourne, Parkville, Victoria, Australia; ${ }^{b}$ Chief Medical Adviser, \\ Jockey Club, London, England
}

\begin{abstract}
Objective: This chapter reviews the current evidence for the epidemiology of pediatric equestrian injuries. Data sources: The relevant literature was searched through the use of MEDLINE (1966-2004) and SPORT DISCUS (1975-2004) searches, hand searches of journals and reference lists and discussions with experts and sporting organizations worldwide. Keywords and Mesh headings used in all searches included horse racing, children, pediatric injuries, sports injuries, equestrian injuries and sports trauma. Main results: Limited data exist on the epidemiology of pediatric equestrian injuries. Most studies note the high preponderance of females with a peak incidence at approximately 14 years of age. This is likely to reflect the higher rate of female riders. The two most common horse ridingrelated injuries are long bone fractures and head injury. Although most injuries occur during recreational riding, approximately $15 \%$ of injuries occur in nonriding activities such as feeding, handling, shoeing and saddling. Conclusions: While there is little knowledge of injury demographics or the efficacy of prevention countermeasures in this field, it is likely that injuries will continue to occur. The major challenge in reducing pediatric equestrian injuries is the formal scientific demonstration that the various proposed injury prevention measures are effective. With the majority of equestrian injuries happening during unsupervised leisure riding, the prospect of injury prevention is limited.
\end{abstract}

Copyright (C) 2005 S. Karger AG, Basel

\section{Introduction}

The demographics and nature of horse riding injuries suffered by children is largely unknown. Although retrospective case series studies have been published, there are no prospective studies detailing these injuries. This is also the case for equestrian injuries in adults, although more information is available in specific subgroups of riders, such as professional jockeys, rodeo riders and polo participants [1]. 
The limited available pediatric injury data are largely a reflection of the way horse riding is conducted. Namely the sport is amateur, variably supervised and apart from limited competitive situations, is not subject to administrative control that would enable the compilation of injury data. Injuries, especially minor injuries, are seldom reported, and there are no regulatory requirements anywhere in the world that compel formal injury notification for this sport. This lack of detailed information is somewhat surprising given that horse riding is one of the most popular participation sports with tens of millions of active riders in most Western countries.

Although falling from horses or being kicked are the most familiar mechanisms of injury, horses can also inflict injuries by biting, pulling, kicking the rider, standing or rolling on the rider and hitting the rider with sudden movement of the head [2]. Further, horses may injure their riders during nonriding activities such as grooming, feeding, handling, shoeing and saddling. Fullygrown horses can weigh up to $550 \mathrm{~kg}(1,200 \mathrm{lbs})$ and are capable of reaching speeds of over $60 \mathrm{kph}(40 \mathrm{mph})$. It is not surprising that severe injuries do occur in this sport [1].

This chapter reviews the current evidence for the epidemiology of pediatric equestrian injuries. The relevant literature was searched through the use of MEDLINE (1966-2003) and SPORT DISCUS (1975-2003) searches, hand searches of journals and reference lists and discussions with experts and sporting organizations worldwide. Keywords and Mesh headings used in all searches included horse racing, children, pediatric injuries, sports injuries, equestrian injuries and sports trauma.

\section{Frequency of Injury}

\section{Participation Level}

There is little or no detailed information about the demographics of pediatric equestrian injuries. Although numerous case series have reported specific injury occurrences, such as catastrophic head or spinal injury, the common thread missing throughout all these studies is information on exposure. Similar criticisms can be made about electronic injury surveillance systems, such as the US national injury surveillance system (http://www.nyssf.org/statistics1998.html) or the North American CHIRPP database (http://www.hc-sc.gc.ca/pphb-dgspsp/publicat/).

In broad terms, the approximate numbers of horse riders is known. In the USA, over 30 million people ride on a regular basis with more than 2 million of these being under the age of 19 years [3-5]. In the UK, this figure is put at 3 million regular participants with one third being children [6]. In Australia, there are over 250,000 people actively engaged in recreational horse riding with 
Table 1. Retrospective and case series studies including pediatric data

\begin{tabular}{|c|c|c|c|c|}
\hline Study reference & Patient source & $\begin{array}{l}\text { Total number } \\
\text { of equestrian } \\
\text { injuries }\end{array}$ & $\begin{array}{l}\text { Number of } \\
\text { injuries }<15 \\
\text { years old } \\
(\% \text { of total })\end{array}$ & Demographics \\
\hline [8] & $\begin{array}{l}\text { Horse Shows } \\
\text { Association survey, } \\
\text { United States }\end{array}$ & 290 & $62(21 \%)$ & $\begin{array}{l}85 \% \text { female } \\
34 \% \text { falls } \\
15 \% \text { fractures }\end{array}$ \\
\hline [8] & $\begin{array}{l}\text { Pony Club survey, } \\
\text { United States }\end{array}$ & 31 & $19(61 \%)$ & $\begin{array}{l}\text { No analysis } \\
\text { performed }\end{array}$ \\
\hline [9] & $\begin{array}{l}\text { Hospital admissions, } \\
\text { United States }\end{array}$ & 136 & NS & $\begin{array}{l}76 \% \text { female } \\
75 \% \text { falls } \\
62 \% \text { fractures }\end{array}$ \\
\hline [10] & $\begin{array}{l}\text { Pediatric } \\
\text { hospital, Norway }\end{array}$ & 23 & $23(100 \%)$ & $\begin{array}{l}90 \% \text { female } \\
60 \% \text { falls } \\
50 \% \text { fractures }\end{array}$ \\
\hline [11] & $\begin{array}{l}\text { National Electronic } \\
\text { Injury Surveillance } \\
\text { System, United States }\end{array}$ & 167,578 & $48,822(29 \%)$ & $65 \%$ female \\
\hline [12] & $\begin{array}{l}\text { National Injury } \\
\text { Database, New Zealand }\end{array}$ & 827 & $315(38 \%)$ & $\begin{array}{l}74 \% \text { female } \\
46 \% \text { fractures }\end{array}$ \\
\hline [3] & $\begin{array}{l}\text { Postal survey, } \\
\text { United States }\end{array}$ & $\begin{array}{l}589(27 \% \text { of } \\
\text { total surveyed })\end{array}$ & $46(8 \%)$ & IR $0.4 / 1,000 \mathrm{~h}$ \\
\hline [13] & $\begin{array}{l}\text { Pediatric hospital data, } \\
\text { Sweden }\end{array}$ & 516 & & $\begin{array}{l}95 \% \text { female } \\
27 \% \text { fractures } \\
\text { IR } 14 / 1,000 \mathrm{~h}\end{array}$ \\
\hline [14] & $\begin{array}{l}\text { Pediatric } \\
\text { Emergency Dept, } \\
\text { United Kingdom }\end{array}$ & 41 & $41(100 \%)$ & $\begin{array}{l}95 \% \text { female } \\
66 \% \text { falls } \\
26 \% \text { fractures }\end{array}$ \\
\hline [15] & $\begin{array}{l}\text { National Pediatric } \\
\text { Trauma Registry, } \\
\text { United States }\end{array}$ & 720 & $276(38 \%)$ & $\begin{array}{l}62 \% \text { female } \\
64 \% \text { falls } \\
35 \% \text { fractures }\end{array}$ \\
\hline [7] & $\begin{array}{l}\text { Australian Bureau } \\
\text { of Statistics data, } \\
\text { Australia }\end{array}$ & 64 & & \\
\hline [16] & $\begin{array}{l}\text { Emergency Dept, } \\
\text { United Kingdom }\end{array}$ & $\begin{array}{l}260(10 \% \text { of } \\
\text { all sports } \\
\text { injuries })\end{array}$ & $62(23 \%)$ & $\begin{array}{l}80 \% \text { female } \\
80 \% \text { falls } \\
60 \% \text { fractures }\end{array}$ \\
\hline
\end{tabular}




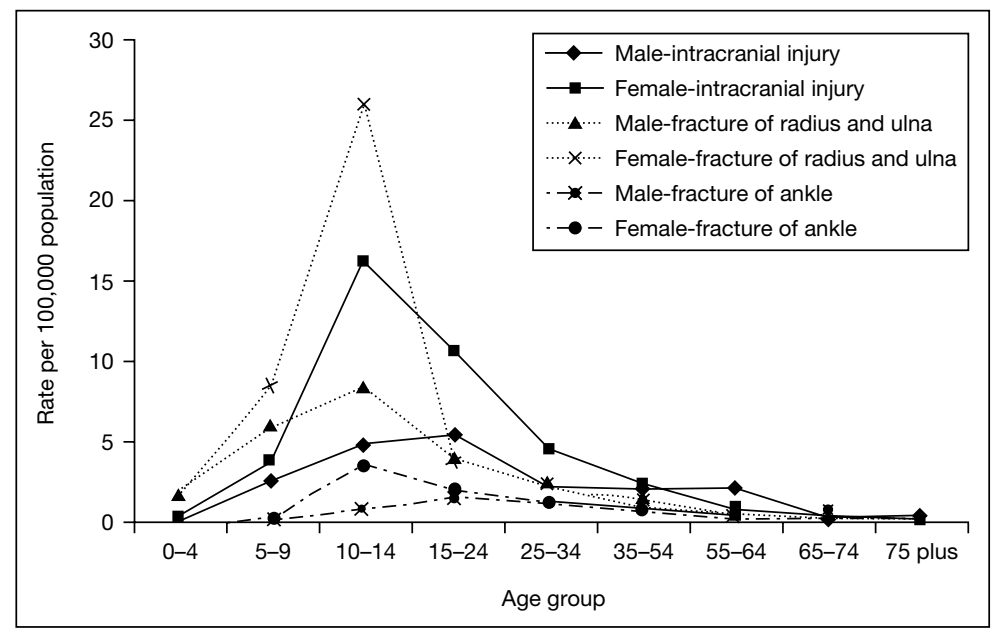

Fig. 1. Specific equestrian injuries by age and sex. Adapted from [7].

74,000 registered child participants in events run by pony clubs and the Equestrian Federation of Australia [7].

Incidence of Injury

A summary of retrospective and case series studies including pediatric data on equestrian injuries is shown in table 1 [3, 7, 8-16]. Virtually all studies note the high preponderance of females suffering horse riding-related injuries (table 1). Crude injury rates of the two most common injuries, long bone fracture and head injury, consistently note higher rates in females and these peak at approximately 14 years of age (fig. 1). This is likely to reflect the higher rate of female riders. However, no precise figures exist in this regard (with the limited exception of pony club membership) to allow accurate analysis of injury rates.

\section{Injury Characteristics}

\section{Injury Onset}

All published studies of equestrian injuries report acute injuries only. There is no published information in the pediatric age group as to whether riders suffer from chronic musculoskeletal injuries related to riding or whether these may contribute to the acute injury episode.

Both Gierup et al. [17] and Williams and Ashby [18] have reported a one third incidence of previous injuries in riders presenting to hospital with a new acute 
injury. No specific details nor exposure information were provided to suggest that the injured riders represent the typical horse riding population.

\section{Injury Location}

Injuries to the extremities comprise the largest group of injuries. They are predominantly soft tissue injuries and long bone fractures [19, 20]. Typically such injuries are not routinely admitted to hospital and may be under-represented in published studies. Equestrian-related head injuries in children are typically admitted to hospital, and hence recorded more accurately.

Head injuries are responsible for the majority of serious equestrian injuries and deaths $[4,6,11,21,22]$. Such injuries are almost invariably related to falls. Injuries to the thorax, abdomen and pelvis are also often severe and account for a smaller but substantial number of hospitalizations $[4,11]$.

\section{Situational}

No information exists as to the situation where injuries occur such as in training or in specific maneuvers such as jumping. The majority of injuries, however, occur during leisure riding rather than in competition [23, 24].

Furthermore, approximately $15 \%$ of equestrian injuries occur in nonriding activities such as feeding, handling, shoeing and saddling $[9,25,26]$.

\section{Action or Activity}

No published information exists regarding the specific activities that were engaged in at the time of the injury with the possible exception of where an injury occurs from a collision between horse and car whilst road riding [6]. Most published studies report mechanisms of injury in terms of falls from the horse or other specific factors related to riding.

\section{Chronometry}

Equestrian injuries tend to occur when the rider is mounted [3, 5, 9, 21, 25], during lessons [26], on farms or in paddocks [18], during warm weather and in school holidays $[6,18]$ and on weekends [18]. These likely represent the most frequent type of riding conducted rather than suggest that they represent a particular propensity to injurious situations.

\section{Injury Severity}

\section{Injury Type}

There are no data available from prospective studies or where the exposure incidence is known that enables injury rate calculation. The published 
retrospective and case series studies are outlined in table 1 and are presented as a percentage of total injuries. Although the broad categories of anatomical injuries are commonly reported, the widely varied methodologies make comparison impossible.

\section{Catastrophic Injury}

Various case series and recommendations have been reported detailing catastrophic head and spinal injury from pediatric equestrian participation $[7,12,16$, 24, 27-36]. In general, fatal head injury from horse riding is relatively low both in general terms and by comparison to other sports $[27,28]$. In one of the few prospective estimates, this horse riding-related mortality risk was put at 0.08 per 100,000 population [7]. This risk estimate includes all age groups.

\section{Time Loss as a Result of Injury}

Limited published information exists and is summarized in the section below. The time lost reported in those studies generally refers to either chronic injuries or those severe enough to warrant hospital presentation. There are no prospective data available for acute injuries.

\section{Clinical Outcome}

No published prospective information exists. There are a variety of case series and retrospective questionnaire-based studies reporting long-term outcome and time lost from equestrian injuries. In general terms, all of these papers suffer from selection bias given the population by which injuries are obtained in addition to the methodological limitations of the study design [5, $14,15,38-42]$.

\section{Injury Risk Factors}

There are no published data on injury prevention or risk factor analysis that have been subjected to formal analysis. In the absence of specific information, a conceptual framework based upon published studies is presented in figure 2 and discussed in the next section.

\section{Suggestions for Injury Prevention}

As discussed above, all suggestions in this section relate to retrospective, case series and other limited data. At best, this could be described as sufficient for Level 3 or 4 recommendations. 


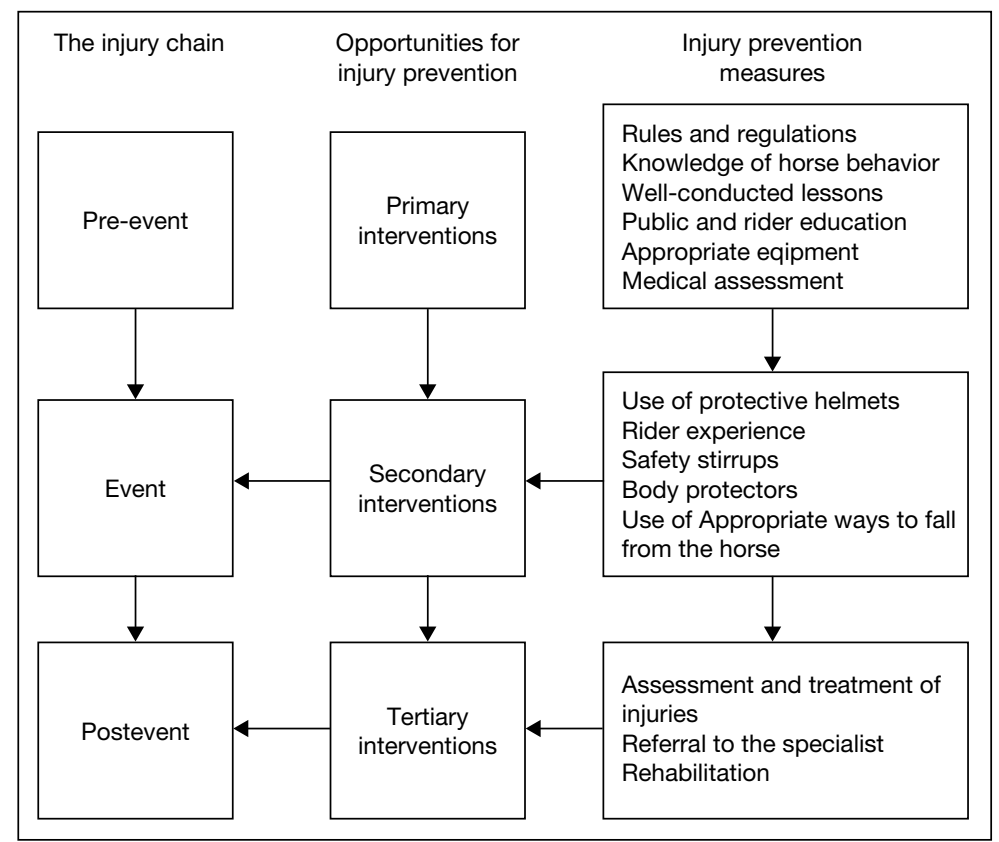

Fig. 2. Injury countermeasures in equestrian sports. Adapted from [10].

\section{Intrinsic Factors}

There are relatively few intrinsic factors that predispose a rider to injury with none that have been validated scientifically. In general, a rider requires a sense of balance, reasonable physical fitness and alertness to ride. Clearly anything that impairs these functions would be a contraindication to riding. In the same manner, avoidance of alcohol and drugs that may impair riding should be mandatory.

Some authors [43] have suggested specific neurological contraindications including unstable spinal cord lesions, permanent sequelae from head injury and repeated painful injury to the cervical and lumbar spine. None of these have been validated prospectively, and would need to be individually assessed.

Rider and public education may assist in informing riders about specific risks with riding and hence alter the behavior toward avoiding such situations as well as encouraging protective equipment use. Although laudable, such campaigns need to be validated against defined outcomes [44].

\section{Extrinsic Factors}

Most equestrian organizations have regulations governing the conduct of the sport and include specific equestrian safety issues. In professional horse racing and to a lesser extent in amateur racing, there are strict licensing requirements, 
supervision of racecourses, veterinary assessment of horses, medical assessment of jockeys, and enforcement of riding and safety rules. Pony clubs and similar groups in the pediatric age group have specific safety standards for supervisors and riders, and strict requirements for helmet use.

Ensuring that riding instructors are certified, experienced and have a good knowledge of horses are all reasonable measures, although no formal analysis has correlated injuries with instruction, and any certification needs to be formally evaluated. Horse selection may have a role whereby instructors can match suitable horses with the level of rider experience. As with all primary prevention measures, the efficacy depends upon both whether the regulations are enforced and whether the safety requirements are themselves effective.

Horse behavior is also a significant factor in many equestrian injuries. In US Pony Club surveys, it has been estimated that up to $80 \%$ of injuries resulted from the behavior of the horse [26]. Although horses are by their very nature unpredictable, some basic principles are important and may be taught as part of the basic horse riding instruction. Warm-up procedures for the horse, rider training, supervisor awareness of aberrant horse behavior, specific instruction in the safe approach to horses and avoidance of situations where other animals or vehicles may frighten a horse, have all been proposed [18, 19]. Specific 'tuck and roll' techniques if dismounted have been suggested as a means, albeit unproven, of reducing injuries in falls [45].

Appropriate and well-maintained equipment (e.g., tack or saddlery) is important to prevent falls. The checking of equipment as part of a premounting and dismounting routine is critical, although it has not been rigorously assessed [46]. Similarly appropriate clothing such as riding boots and gloves are important.

Protective equestrian helmets are widely recommended. Such helmets need to be certified to an appropriate materials testing standard. Although they are widely recommended, there has been no formal prospective or controlled study conclusively demonstrating their benefit or, in fact, that the current helmet standards are adequate to prevent injury [19]. There is some anecdotal evidence, however, suggesting a benefit for helmet use in preventing or lessening the severity of head injuries $[33,47]$. Similarly other safety equipment such as body protectors and safety-release stirrups remain unproven.

\section{Suggestions for Further Research}

The major challenge facing pediatric equestrian injuries is the formal scientific demonstration that the various proposed injury prevention measures are effective. Ideally, this should be performed before they are implemented or promoted. In addition, the barriers to the adoption of injury prevention measures should be studied. 
Given the high participation in organized instructional programs such as Pony Club, an assessment of the effectiveness of rider (and supervisor) training should be undertaken. External accreditation of instructors and riding schools should be performed to set standards that have been independently verified.

With the majority of equestrian injuries happening during unsupervised leisure riding, the prospect of injury prevention is reduced. Rider education campaigns to ensure adequate training, maintenance and inspection of equipment, wearing of appropriate clothing and helmets may all assist in reducing injuries.

While there is so little knowledge of injury demographics or the efficacy of prevention countermeasures in this field, it is likely that injuries will continue to occur.

\section{References}

1 Turner M, McCrory P, Halley W: Injuries in professional horse racing in Great Britain and the Republic of Ireland during 1992-2000. Br J Sports Med 2002;36:403-409.

2 Regan P, Roberts J, Feldberg L, Roberts A: Hand injuries from leading horses. Injury 1991; 22:124-126.

3 Nelson D, Rivara F, Condie C, Smith S: Injuries in equestrian sports. Phys Sportsmed 1994;22: 53-60.

4 Bixby-Hammett D: Youth accidents with horses. Phys Sportsmed 1985;13:105-108.

5 Nelson D, Bixby-Hammett D: Equestrian injuries in children and young adults. J Trauma 1999;3: $7-11$.

6 Silver J, Lloyd-Parry J: Hazards of horse riding as a popular sport. Br J Sports Med 1991;25: 105-110.

7 Cripps R: Horse-related injury in Australia. Australian Injury Prevention Bulletin 24. Adelaide, Research Centre for Injury Studies, Flinders University, May 2000. Report No.: AIHW Cat. No. INJ26.

8 Bernhang A, Winslett G: Equestrian injuries. Phys Sportsmed 1983;11:90-97.

9 Barone GW, Rodgers BM: Pediatric equestrian injuries: A 14-year review. J Trauma 1989;29: 245-247.

10 Sahlin Y: Sports accidents in childhood. Br J Sports Med 1990;24:40-44.

11 Bixby-Hammett D, Brooks WH: Common injuries in horseback riding. A review. Sports Med 1990;9:36-47.

12 Buckley S, Chalmers D, Langley J: Injuries due to falls from horses. Aust J Pub Health 1993;17: 269-271.

13 Sorenson L, Larsen S, Rock N: The epidemiology of injuries in school age children. Scand J Med Sci Sports 1996;6:281-286.

14 Campbell-Hewson GL, Robinson SM, Egleston CV: Equestrian injuries in the paediatric age group: A two-centre study. Eur J Emerg Med 1999;6:37-40.

15 Ghosh A, Di Scala C, Drew C, Lessin M, Feins N: Horse-related injuries in paediatric patients. J Paediatr Surg 2000;35:1766-1770.

16 Moss P, Wan A, Whitlock M: A changing pattern of injuries to horse riders. Emerg Med J 2002;19: $412-414$.

17 Gierup J, Larsson M, Lennqvist S: Incidence and nature of horse riding injuries. Acta Chirur Scand 1976;142:57-61.

18 Williams F, Ashby K: Horse related injuries, ed 23. Melbourne, Victorian Injury Surveillance System, 1995. 
19 Watt GM, Finch CF: Preventing equestrian injuries. Locking the stable door. Sports Med 1996;22:187-197.

20 Lim J, Puttaswamy V, Gizzi M, Christie L, Croker W, Crowe P: Pattern of equestrian injuries presenting to a Sydney teaching hospital. ANZ J Surg 2003;73:567.

21 Nelson DE, Bixby-Hammett D: Equestrian injuries in children and young adults. Am J Dis Child 1992;146:611-614.

22 Lloyd RG: Riding and other equestrian injuries: Considerable severity. Br J Sports Med 1987;21: 22-24.

23 Whitlock MR, Whitlock J, Johnston B: Equestrian injuries: A comparison of professional and amateur injuries in Berkshire. Br J Sports Med 1987;21:25-26.

24 MMWR: Horseback riding associated traumatic brain injury - Oklahoma 1992-1994. MMWR 1996;45:209-211.

25 Hobbs GD, Yealy DM, Rivas J: Equestrian injuries: A five-year review. J Emerg Med 1994;12: 143-145.

26 Bixby-Hammett DM: Accidents in equestrian sports. Am Fam Physician 1987;36:209-214.

27 Nicholl J, Coleman P, Williams B: The epidemiology of sports and exercise related injury in the United Kingdom. Br J Sports Med 1995;29:232-238.

28 Nicholl J, Coleman P, Williams B: Injuries in sport and exercise. London, Medical Care Research Unit and Sports Council, November 1991. Report No.: ISBN 1-872158-71-4.

29 Silver J: Spinal injuries from horse riding accidents. Spinal Cord 2002;40:264-271.

30 Silver J: Spinal injuries in sports in the UK. Br J Sports Med 1993;27:115-120.

31 Ingermarson H, Grevsten S, Thoren L: Lethal horseriding injuries. J Trauma 1989;29:25-30.

32 Bixby-Hammett DM: Pediatric equestrian injuries. Pediatrics 1992;89:1173-1176.

33 Bond GR, Christoph RA, Rodgers BM: Pediatric equestrian injuries: Assessing the impact of helmet use. Pediatrics 1995;95:487-489.

34 Christey GL, Nelson DE, Rivara FP, Smith SM, Condie C: Horseback riding injuries among children and young adults. J Fam Pract 1994;39:148-152.

35 CDC: Injuries associated with horseback riding - United States 1987/1988. JAMA 1990;264:18-19.

36 Pediatrics AAo: Horseback riding and head injuries (Statement from the Committee on Sports Medicine and Fitness). Pediatrics 1992;89:512.

37 Dekker R, Sluis C, Koostra J, Groothof J, Eisma W, Duis H: Long term outcome of equestrian injuries in children. Disabil Rehab 2004;26:91-96.

38 Dekker R, Sluis C, Groothof J, Eisma W, Duis H: Clinical treatment of equestrian injuries in Groningen, 1990-1998: Serious long term effects. Ned Tijdschr Geneeskd 2003;147:204-208.

39 Dekker R, Sluis C, Koostra J, Groothof J, Eisma W, Duis H: Long term outcome after sports injuries: Results after inpatient treatment. Clin Rehabil 2003;17:480-487.

40 Sorli JM: Equestrian injuries: A five-year review of hospital admissions in British Columbia, Canada. Inj Prev 2000;6:59-61.

41 Dekker R, Sluis C, Koostra J, Groothof J, Eisma W, Duis H: Long term disabilities and handicaps following sports injuries: Outcome after outpatient treatment. Disabil Rehab 2003;25:1153-1157.

42 Giebel G, Braun K, Mittelmeier W: Equestrian accidents in children. Chirurg 1993;64:938-947.

43 Brooks W, Bixby-Hammett D: Prevention of neurologic injuries in equestrian sports. Phys Sportsmed 1988;16:84-95.

44 Thompson J, Von Hollen B: Causes of horse-related injuries in a rural Western community. Canadian Fam Physic 1996;42:1103-1109.

45 Bliss T: How to save yourself from riding injury. Practical Horseman 1988;16:36-43.

46 Firth J: Equestrian injuries; in Schneider R, Kennedy J, Plant M (eds): Sports Injuries: Mechanism, Prevention and Treatment. Baltimore, Williams and Wilkins, 1985, pp 431-449.

47 Bixby-Hammett D: USPC completes 10-year accident study. USPC News 1992.

Assoc. Prof. Paul McCrory, PhD, MB, BS

Editor, British Journal of Sports Medicine

200 Berkeley St., Parkville, Victoria 3052 (Australia)

Tel. +6138344 4118, Fax +61 38344 3771, E-Mail pmccrory@compuserve.com

Pediatric Equestrian Injuries 